\title{
Veda a umenie bez bariér
}

\author{
Iveta Bónová - Lucia Jasinská (Košice)
}

Možnost predstavit výsledky vlastných výskumov či teoretické koncepcie a získat pritom erudovanú spätnú väzbu, ako aj nájst' inšpiráciu na d’alšie vedecké či umelecké smerovanie je dôležitou súčastou profilu každého vysokoškolského pedagóga a vedca $\mathrm{v}$ jednej osobe. $\mathrm{Z}$ uvedenej požiadavky vyvstáva potreba odborne zameraného stretnutia, ktoré sa uskutočnilo začiatkom marca v metropole východného Slovenska.

V dňoch 6. - 8. 3. 2019 sa na pôde Filozofickej fakulty Univerzity Pavla Jozefa Šafárika v Košiciach konalo vedecko-umelecké sympózium Veda a umenie bez bariér. Podujatie bolo organizované v rámci projektu KEGA č. 008UPJŠ-4/2017 Veda bez bariér (Interdisciplinárne inšpirácie súčasnej literárnej vedy a jazykovedy v edukačnej praxi $n a V S \check{\text { ) }}$ ako jeden z naplánovaných projektových zámerov. Na príprave sympózia, v spolupráci s košickou pobočkou Slovenskej jazykovednej spoločnosti pri JÚLŠ SAV, sa organizačne podielali Iveta Bónová a Lucia Jasinská z Katedry slovakistiky, slovanských filológií a komunikácie FF UPJŠ. Organizáciu umeleckej zložky sympózia zabezpečila Ivica Hajdučeková v spolupráci so Školou úžitkového výtvarníctva v Košiciach

Úvodné slovo na sympóziu patrilo prof. Jánovi Gbúrovi, prorektorovi UPJŠ a zároveň vedúcemu projektu, ktorý objasnil jeho ciele a zameranie. Účastníkov podujatia v Historickej aule Filozofickej fakulty UPJŠ privítala aj dekanka fakulty prof. Olga Orosová. Samotné podujatie slávnostne otvorila zástupkyňa predstaveného projektu doc. Ivica Hajdučeková.

Počas troch vedecky, odborne aj umelecky nasýtených dní boli predstavené výskumy a podnety z okruhu slovakistiky v interdisciplinárnych súvislostiach, v rámci ktorého sa niektorí prednášajúci zamerali na skúmanie jazyka.

Otázkam a výzvam súčasnej spisovnej slovenčiny - jednotlivo so zameraním na zvukové, lexikálne či morfologické javy - sa vo svojich plenárnych príspevkoch venovali jazykovedci z viacerých slovakistických pracovísk: Slavomír Ondrejovič (JÚL'S SAV v Bratislave), Miloslava Sokolová, Daniela Slančová (FF PU v Prešove) a Pavol Odaloš (FF UMB v Banskej Bystrici). O význame a stave slovakistiky na zahraničných univerzitách informovala Jana Pekarovičová (FF UK v Bratislave). Vladimír Patráš (FF UMB v Banskej Bystrici) dopoludňajší program prvého rokovacieho dňa ukončil predstavením podstaty revidovaného študijného odboru filológia s jeho možnými interdisciplinárnymi presahmi.

Viaceré lingvistky - Mária Šimková (JÚLŠ SAV v Bratislave), Katarína Gajdošová (JÚĽS SAV v Bratislave), Iveta Bónová a Lucia Jasinská - predostreli výsledky svojho bádania založené na korpusových výskumoch, pričom v previazanosti na praktické využitie v nich mapovali stav synchrónneho jazyka. Zvukovej rovine sa na segmentálnej a suprasegmentálnej rovine vo svojich príspevkoch venovali aj Renáta Gregová a Lena Ivančová. Lexikálny výskum na synchrónnej aj diachrónnej osi priblíżili Lujza Urbancová (FF UMB v Banskej Bystrici) a Marianna Sedláková.

V tematicky literárne a médiologicky ladených príspevkoch boli prednesené výsledky literárnovedných výskumov, v rámci ktorých sa referujúci popri univerzálnejších témach - aj v súvislosti s nosnou líniou projektu - zamerali na ženy „v zrkadle“ literárnej vedy a médiológie.

K literárnoteoretickým patril príspevok Miloša Zelenku (PF JU v Českých Budějoviciach), ktorý uvažoval o postavení verzológie medzi filológiou a ideológiou, a Jany Kuzmíkovej (Ústav slovenskej literatúry SAV v Bratislave), ktorá sa zaoberala vztahom estetiky a kognitívnej literárnej vedy v slovakistike. Anna Zelenková (Slovanský ústav AV ČR) sa vo svojom vstupe venovala najnovšiemu výskumnému objavu, tzv. wollmanovskému moravskému zberu ludovej prózy. O význame umenia v semióze kultúry referoval Lukáš Šutor. 
Príspevky Mariána Milčáka a Aleny Oravcovej priniesli poznatky z oblasti literárneho výskumu venovaného poézii. Potrebu interdisciplinárneho prístupu vo vyučovaní svetovej literatúry vo svojom príspevku zdôraznila Anna Valcerová (FF PU v Prešove) a problematikou prekladu básnickej tvorby sa vo svojom referáte zaoberal Marián Andričík.

Prozaickej tvorbe autorov sa vo svojich príspevkoch venovali doktorandky z hostujúceho pracoviska - Andrea Fedorková, Patrícia Havrila, Ivana Kovalíková a Patrícia Papcunová. Poetike súčasnej literárnej tvorby ženských autoriek sa venovala Marta Součková (FF PU v Prešove). V súvislosti so ženskou tematikou Patrik Šenkár (PF Univerzity J. Selyeho v Komárne) orientoval svoj príspevok na hrdinky v slovenskej literatúre v zahraničí.

Médiologicky orientované podnety odzneli vo vystúpeniach troch referujúcich - Juraj Rusnák (FF PU v Prešove) sa venoval formátu celebrity, Gabriela Homol'ová predstavila významné ženy košického televízneho štúdia a Igor Michalčík sa zameral na ženské interpretky v rozhlasovej hre.

Charakteristiku obdobia literárneho realizmu v domácom prostredí cez analýzu diel konkrétneho autora, resp. autorky, vo svojich príspevkoch spracovali Dana Hučková (Ústav slovenskej literatúry SAV v Bratislave) a Lívia Barnišinová. V záverečnom referáte podujatia Ivica Hajdučeková predstavila výsledky výskumu časopisu Živena v poprevratovom období Československej republiky s dôrazom na rozširovanie obzoru ženských čitateliek.

Špecifickým bol prostredný deň sympózia, ktorý bol symbolickým pristavením sa pri významnom životnom jubileu slovenského jazykovedca Dr. h. c. prof. PhDr. Jána Sabola, DrSc.
Po pozdravoch jubilantovi od dekanky fakulty, ako aj od iných účastníkov podujatia a zástupcov jednotlivých inštitúcií, s ktorými jubilant spolupracoval, prebiehalo prednáškové plénum, na ktorom predstavili svoje dlhodobé výskumy na poli lingvistiky domáci aj zahraniční prednášajúci. V úvode prof. Ján Sabol predniesol svoje úvahy o semiotických väzbách metafory a metonymie. Po teoreticko-metodologicky koncipovanom referáte jubilanta vystúpili jeho dvaja dlhoroční spolupracovníci a členovia komisie pre fonetiku a fonológiu slovanských jazykov pri Medzinárodnom komitéte slavistov: Irena Sawicka (Instytut Slawistyki PAN vo Varšave) referovala o mechanizmoch konvergencie $\mathrm{v}$ podmienkach multilingvizmu a Damir Horga (FF Univerzity v Záhrebe) analyzoval a kontextovo charakterizoval atribúty reči v elektronickom mediálnom prostredí súčasnosti. Slávnostný charakter dňa bol v priestoroch univerzitnej kaviarne Minerva podčiarknutý vernisážou Literatúra cez objektív, na ktorej študenti Školy úžitkového výtvarníctva v Košiciach pod vedením svojich pedagogičiek predstavili digitálne spracované návrhy k umeleckým dielam z obdobia slovenského realizmu.

V priebehu troch dní sa programom vedecko-umeleckého podujatia naplnil očakávaný zámer jednej z plánovaných projektových aktivít. Výstupom zo sympózia je zborník abstraktov, v ktorých prednášajúci predstavujú ciele, metódy a klúčové výsledky svojich výskumov, aby sa aj širšia odborná verejnost̉ mohla oboznámit s obsahovou náplňou tohto podujatia. Za organizačný tím vyjadrujeme potešenie z podnetného stretnutia plného vedeckých osobností, odborných diskusií, umeleckých zážitkov, ale aj ludsky príjemných okamihov.

PhDr. Iveta Bónová, PhD. / iveta.bonova@upjs.sk - PhDr. Lucia Jasinská, PhD. / lucia.jasinska@upjs.sk

Katedra slovakistiky, slovanských filológií a komunikácie

Filozofická fakulta, Univerzita Pavla Jozefa Šafárika

Moyzesova 9, 04011 Košice, Slovensko

Toto dílo Ize užít v souladu s licenčními podmínkami Creative Commons BY-SA 4.0 International (https://creativecommons.org/licenses/by-sa/4.0/legalcode). Uvedené se nevztahuje na díla či prvky (např. obrazovou či fotografickou dokumentaci), které jsou v díle užity na základě smluvní licence nebo výjimky či omezení příslušných práv. 